fieldwork. In later stages she became closely involved in many of the women's lives but retained a rigorous approach to the theoretical, conceptual and ethical quandaries that lay at the heart of the study.

This is an important book. Of course, the small sample it describes is not representative of HIV positive women in general or even of those in the USA. As Berger herself points out, the women were self selected and were healthy at the time of interview. But the analysis provides fertile ground for further work in a number of different areas. As anti-retroviral drugs become more effective, HIV is increasingly becoming a chronic illness instead of a terminal disease, at least in those countries where they are available. This highlights the importance of further studies of this kind that explore the HIV experience in gender sensitive ways across a range of different social, economic and cultural settings.

doi:10.1057/palgrave.fr. 9400401

Lesley Doyal

\title{
Sistering: power and change in female relationships
}

Melanie L. Mauthner; Palgrave Macmillan, Houndmills, Basingstoke, Hampshire, 2002, 240p, ISBN 1-4039-4125-4/GBP 15.99 (Pbk)

Melanie L. Mauthner began her research on biological sister relationships in 1993 when she observed that work on sistering was notable for its absence in academic studies and social policy. She states that 'one paradox about sistering is that, although it is a widespread female experience, sistering practices remain largely invisible' (p. 13). Mauthner's qualitative approach to her research eventually led to writing her dissertation on the topic. Sistering: power and change in female relationships is the book adaptation of that dissertation. I was first drawn to this work because I am the eldest of five siblings: I have three brothers and one sister. Over the years my relationship with my sister has weathered many of the changes chronicled by Mauthner. My sister Jeanette and I were born fifteen months apart and we have spent the last fifty-six years serving as sisters to each other. I learned a great deal about my sister self in reading this text.

Feminist theory provides a framework for the research. The data were collected using an autobiographical approach. Mauthner draws upon both standpoint and post-structuralist theory in analysing the data she collected. The major questions that Mauthner explores are: 'What is sistering and what are women's experiences of it?' (p. 1). Early on, Mauthner establishes the boundaries of her work: 
The book forms part of a sociological and post-structural project rather than a psychological or psychoanalytic one. It explores the role of caring and power relations in the lives of girls and women growing up as sisters, rather than impact of birth order, the age gap or rivalry. Its focus is the social dimension of sistering between women, as opposed to the sistering of men or brothering (p. 2).

The population used for this study consisted of thirty-seven girls and women aged six to fifty. The majority of the age groups represented were women in their teens, twenties, thirties, and forties. The women were located by employing a snowballing technique. The participants represented diverse socio-economic and ethnic backgrounds and although many of the women came from various geographical locations, at the time the data were collected, all thirty-seven sisters lived in England.

The research examines in detail what Mauthner calls 'distinct contact patterns' (p. 11) of best friendship, close and distant companionship, mini-mother or cared-for sister. In threading these themes together, Mauthner examines how caring, power and friendship are present in sister relationships. Sistering shares these themes with other gendered family relationships, notably mother and daughtering. These contact patterns are not necessarily static; indeed many changed over time. Changes occurred because of transitions related to life events such as changing schools, bereavement, divorce, leaving home, beginning or changing jobs, and becoming a mother. 'The main factors accounting for the process of relationships changing over time were age and life stage' (p. 172). Like these external changes, sistering may also change patterns because of 'internal shifts triggered by factors additional to age and life stage: fluctuating power relationships, and subjectivity' (p. 173).

The structure of the book is sound. The chapters are arranged to provide an indepth treatment of the topics listed: sistering and friendship, buddies and best friends, power relationships, motherly sistering, kindred spirits, lovers and marriage, divorce and bereavement, changing subjectivity. These chapters are followed by a concise conclusion. Mauthner furnishes an appendix which provides biographical data on each of the sister sets. This is followed by a second appendix that discusses and analyses the study's methodology. The excellent bibliography spans nineteen pages; this will be a useful resource for scholars interested in investigating aspects of sistering. The index is equally useful; it is specific and lengthy.

Mauthner asserts that her goal in conducting the research and publishing this book was to 'extend the research on family life' to add 'to our understanding of a same-sex tie' and to chart 'continuity and change in sistering' (p. 173). Does Mauthner accomplish what she tells the reader she set out to do? The answer is an unqualified affirmative. She sheds light on an aspect of women's lives that hitherto existed in mere shadows. Sistering: power and change in female 
relationships will serve as a guide for further explorations in feminist scholarship on the role of sistering in our lives.

doi:10.1057/palgrave.fr. 9400396

\section{Glenda Lewin Hufnagel}

\section{Donna Haraway Live Theory}

Joseph Schneider; Continuum, New York and London, 2005, ISBN 0-8264-6279-0, £12.99 (Pbk); ISBN 0-8264-6278-2, £45.00 (Hbk)

\section{Hélène Cixous Live Theory}

Ian Blyth with Susan Sellers; Continuum, New York and London, 2004, ISBN 0-8264-6680-X, £12.99 (Pbk); ISBN 0-8264-6679-6, £45.00 (Hbk)

\section{Julia Kristeva Live Theory}

John Lechte and Maria Margaroni; Continuum, New York and London, 2004, ISBN 0-8264-6356-8, £12.99 (Pbk); ISBN 0-8264-6355-X, £45.00(Hbk)

To date, there have been ten volumes published in Continuum's Live Theory series. The series consists of critical, but introductory books about influential contemporary cultural theorists and philosophers. Half of the books published so far engage specifically with a feminist scholar, and the entire list consists of books on scholars influential in the field of feminist scholarship: Jean Baudrillard, Judith Butler, Noam Chomsky, Hélène Cixous, Jacques Derrida, Donna Haraway, Fredric Jameson, Julia Kristeva, Gayatri Chakravorty Spivak, and Slavoj Žižek. In some cases the authors of the volumes are among the theorist's most severe critics. This is the case, for instance, with the book on Butler, which is written by Australian feminist Vicki Kirby. Live Theory exists alongside series such as Routledge Critical Thinkers or Continuum's Guides for the Perplexed: introductory texts focussing on one contemporary theorist, mainly feminist or postcolonial philosophers or theorists from the humanities. As a relatively young series Live Theory has been able to arrange quite a line-up, and as such, it has the potential of becoming an important player on the academic publishing market.

The three books reviewed here are Donna Haraway Live Theory, Julia Kristeva Live Theory, and Hélène Cixous Live Theory. Donna Haraway Live Theory came out in 2005. The text is written by Joseph Schneider, a US-based sociologist whose earlier work includes writing and teaching on Haraway's work. One of his texts engages with Haraway's diffraction in ethnographic methodology. Diffraction is one of Haraway's innovative concepts. It is introduced so as to avoid the categories 'original' and 'copy' that form the basis of reflection. It engages with a prism rather than a mirror, and focuses on the 'event'. Schneider has set out to 